This is an Accepted Manuscript of an article published by Taylor \& Francis in The European Journal of the History of Economic Thought on February 20, 2020, available at https://www.tandfonline.com/doi/full/10.1080/09672567.2020.1720765.

\title{
Marxism before Marxism: Nikolaj Sieber and the birth of Russian social-democracy ${ }^{1}$
}

François Allisson, Université de Lausanne

Federico D’Onofrio, Unviersità di Venezia Ca'Foscari (corresponding author)

Danila E. Raskov, Sankt-Peterburgskij Gosudarstvennyj Universitet

Leonid D. Shirokorad, Sankt-Peterburgskij Gosudarstvennyj Universitet

The Swiss-Russian economist Nikolaj Sieber was one of the first who wrote about Marx in Russia. In this article we reconstruct the development of his thought by mobilising evidence about the intellectual and political context he lived in. We document his involvement within the Ukrainian national movement of the 1870s and argue that this closeness was consistent with his take on the capitalist evolution of the Russian Empire. We discuss his importance in the Russian debates on the future of the peasant commune and of Russia and conclude that his interpretation of Marx and capitalism was crucial for the development of the Russian social-democratic party.

Keywords: Nikolaj Sieber; Marxism; Marx; Russia; future of capitalism

JEL B14, B31, P10

\footnotetext{
${ }^{1}$ This article is based on the results of the project IZLRZ1_163856, Scientific \& Technological Cooperation Programme Switzerland-Russia (STCPSR) of the Swiss National Science Foundation. The authors thank two anonymous reviewers, Hanna Perehoda, Ilija Magin, the members of the Mokum community for their assistance in St. Petersburg and Kyiv. While most of the characters that appear in this story were ethnic Ukrainians, almost all our sources are in Russian and we have therefore decided to transliterate the Russified version of names of people and places that appeared in the sources, therefore Kiev rather than Kyiv, Mikhail Dragomanov rather than Mihailo Drahomaniv, etc. In transliterating Russian names, we have adopted the simple - without diacritics - system named GOST 16876-71B.
} 


\section{Introduction}

In February 1881 the Russian revolutionary activist Vera Zasulich sent a letter to Karl Marx asking about the future of Russia and the Russian rural commune - the obshchina: should the "revolutionary socialists" free the traditional peasant communities so that they could develop in a socialist direction, or should they recognize the necessity of a capitalist phase in Russia and wait "for capitalism in Russia to reach something like the level of development already attained in Western Europe"? On the issue whether every country was necessarily to undergo a capitalist phase, the Russian revolutionary movement - as it is well known - had split. The populists and the anarchists imagined that a swift revolution could spare the experience of capitalist contradictions to the working class, by freeing traditional institutions such as the rural commune from their subordinate positions. Others believed that a capitalist phase was necessary for the forces of production to reach such a level of development that would make a socialist revolution possible. Both groups relied on the authority of Marx, but which group was rightly interpreting him?

After many hesitations, Marx answered that he believed the Russians should not necessarily wait for capitalism to develop, but none of the members of Zasulich group, ever discussed this answer. Gareth Stedman Jones ended his recent biography of Karl Marx quoting David Rjazanov, director of the Institute Marx-Engels in the 1920s. He knew that the answer had been sent and recalled rumours "of a personal confrontation between [Georgij] Plekhanov, who was said to have denied communal property [obshhina], and Karl [Marx], who was said to have defended it." (Stedman Jones 2017, 595). Whether this direct confrontation with the old master ever took place, the fact is that Zasulich, Plekhanov and their friends split from the populist groups, created the Emancipation of Labour Group and shared with the mainstream Marxists of Europe the conviction that, based on Marx' teaching, a capitalist phase was indispensable before 
the socialist revolution was possible. In this article, we argue that Nikolaj Ivanovich Sieber (1844-1888) is the missing piece between Marx, the concerns of the socialists of the $1860 \mathrm{~s} / 70 \mathrm{~s}$, and these new Marxists of the 1880s. When they converted to Marxism, the members of the "Emancipation of Labour Group", Plekhanov, Zasulich, Dejch and Aksel'rod, adopted Sieber's rather than the late Marx's position on the inevitability of capitalism and relegated the obshchina to the populist dustbin of history. Zasulich's letter, therefore, witnesses a phase in the development of the Russian socialist movement, in which Sieber had a crucial influence, providing a "correct" reading of Marx and the "right" interpretation of the philosopher's predictions about Russia's future.

Sieber is mostly famous as an early populariser of Karl Marx in Russia and translator of Ricardo. His main claim to fame therefore has been until recently, Marx's praise of Sieber's "consistent and firm grasp of the purely theoretical position" in the Afterword to the second German edition of Das Kapital (Marx 1873, 21). ${ }^{2}$ His dissertation, David Ricardo's Theory of Value and Capital (Sieber 1871, in Russian) occupies, in fact, a special place in this respect. ${ }^{3}$ It contains the first influential exposition and evaluation of the economic theories of Marx in Russian literature and it enabled Sieber, during his lifetime and beyond, to leave an enduring mark on the reception of Marx in Russia. Influenced decisively by the reading of Zur Kritik der Politischen Oekonomie and Das Kapital, over the course of his short life, he insisted on the historical nature of capitalism, testified to the inroads of capitalism into Russia and investigated the rise and fall of communal property among the ancients and the moderns.

\footnotetext{
${ }^{2}$ Karl Marx read Sieber's 1871 book, and even annotated it. The copy is located at the International Institute of Social History in Amsterdam (IISG, R 165/102 K). See Marx and Engels (1999, 691-92).

${ }^{3}$ The authors of this paper are preparing the first English edition of this work.
} 
We try here to reconstruct the complexity of his biography following, at the same time, a largely chronological order and the development of his ideas. This is an arduous task that required us to follow Sieber's trace across different countries and investigate his connections with clandestine movements in the Russian Empire and adopt new perspectives, significantly different from the previous literature. Despite a recent revival of interest in Sieber both in connection with the history of early Marxism and in relationship with the study of the intellectual life of $19^{\text {th }}$ century Ukraine, his biographies remain fundamentally outdated.

James D. White has been instrumental in beginning a reassessment of Sieber's role, especially by underlining the importance of Marx continued discussions with the Russians in the emergence of dialectical materialism. White $(1996,2019)$ documented Marx's connections with a group of Russian scholars, including Sieber, who were interested in the understanding the role of Russia in a capitalist world and the future of traditional societies. François Allisson (2015, 240ff.) showed the striking parallel of Tugan-Baranovskij's synthesis and Sieber's value theory. The first section of this article deals therefore with the first theoretical work that Sieber produced on Marx during his student years in Kiev and shows how Marx' historical materialism and understanding of the logic of capitalism enabled the young economist to reconcile the German and British school of political economy while transcending both.

Recent Ukrainian historiography, in a nationalist attempt at appropriating Sieber, insisted on his acquaintance with well-known Ukrainophiles, such as Mikhail Dragomanov and Sergej Podolinskij. The question of Sieber's role in the Ukrainian nationalist movement had already been debated in Czarist Russia (Vol'kov and Rusov 1907), and then again after the Revolution, until D. B. Naumov, on the eve of Stalin's purge, closed the debate by documenting that Sieber took part into a number of 
activities of the Ukrainophiles and stating that Sieber had "a relatively little active role" in the "Ukrainian movement of the 1870s and 1880s" (Naumov 1930,17). Recent literature in Ukrainian tended, instead, to stress Sieber's ukrainophilia but without adding any significant new documentary evidence (for instance Visnik kï̈vs'kogo nacional'nogo universitetu imeni Tarasa Shevchenka, economics, 96/2007 and Pavlenko 2012). The second section examines the political positions of the Ukrainian circles to which Sieber belonged. It takes into account the importance of federalist ideals in the European socialist movement during the 1860s and 1870s and rid the Ukrainophiles of misleading characterizations as liberal-bourgeois nationalists. It also shows how the economist collected empirical material to prove the emergence of a capitalist economy in the Southwestern provinces of the Empire.

The third section analyses Sieber influential presence in the pages of Russian journals, as he wrote on the evolution of land-property in western Europe, on the economic cycle, and on Marx and Engels' economic theories. He was an economist recognised by those who, although interested in Marx's description of capitalism, managed to remain within the legal framework of the Russian Empire, taught in the imperial universities and published their articles in the journals of Moscow and Petersburg. For this reason Sieber has often been regarded as the father of "legal Marxism". Andrzej Walicki (1969), for instance, believed that "it was Ziber, and nobody else, who initiated the liberal-economic interpretation of Marxism, an interpretation taken up later by the 'legal Marxists."'

In fact, thanks to new archival findings and a re-examination of published materials, we propose to consider Sieber as a crucial influence on Russian revolutionary Marxism. The topic of Sieber's alleged inability to understand revolutionary dialectic is 
very delicate. ${ }^{4}$ Very early on, based on judgements by memorialist Dimitri OvsjanikoKulikovskij and Plekhanov himself, Soviet historiography came to deny Sieber's revolutionary engagement..$^{5}$ Archival materials show Sieber's proximity to Peter Lavrov who did support a revolutionary program but believed - in contrast with other populists and the anarchists - that the revolution should be preceded by a relatively long period of education of the people. While it is impossible to draw definitive conclusions, there are reasons to think, as we will show in the fourth section, that Sieber actually believed in the socialist revolution but only as the final stage of a long educational work and that he passed on this teaching to Aksel'rod and the others in the Emancipation of Labour group.

\section{Marx between Ricardo and the Germans}

Sieber was born in Sudak in Crimea, in 1844. His father, Johan, a native of Fluntern near Zurich, had migrated to Russia, like many Swiss of his generation, looking for fortune in the early decades of the $19^{\text {th }}$ century. He was a chemist and lived in Nizhnyj Novgorod and probably elsewhere before landing in Crimea (See Bühler et al. 1985, 297-98, 414 and SZH: VIII E 39 (Familienbuch Fluntern 1889 bis 1892)). Sieber's mother, Anna Fierfort, was of French descent but she was probably russified and orthodox, since her son appears to be a Christian orthodox (DAK, Fond 16, opis' 314, delo 163. Lists 24 and 25). Sieber studied in the Gymnasium of Simferopol and then moved to Kiev, where he enrolled in the faculty of law to study political economy (Zuev 1898; Lichnoe delo N.I. Zibera, DAK, 16-314-163). The roots of Sieber's Marxism and of his approach to economics can be traced back to his formative years at

\footnotetext{
${ }^{4}$ The most recent example of this attitude in Mullin's brief and dismissive mention of Sieber (Mullin 2015, 7).

${ }^{5}$ See Shtejn (1948); Krandievskij (1966); Polyanskij (1965).
} 
the Saint Vladimir Imperial University of Kiev. To him and to the turbulent generation of the 1860s, Marx's writings about capitalism must have appeared as a solution to theoretical problems as well as a key to understand the chaotic world outside academia. The first version of his main theoretical piece of work - David Ricardo's Theory of Value and Capital (1871) - emerged in this context.

Sieber earned his first degree in 1866, then continued studying thanks to a grant from 1868 to 1871 and obtained his master degree in 1871. Sieber's professors of political economy at the time were Nikolay Khristianovich Bunge (1823-1895) and Grigory Matveevich Cekhanoveckij (1833-1898). Professor Alexandr Vasilievich Romanovich-Slavatinskij (1832-1910), who taught a course on foreign constitutional law at St. Vladimir's in the early 1860s, and was also influential in Sieber's education, noted that

It was this school in which N. Sieber began his economic education, under the wing of Professor Bunge, who was quite attentive and caring towards Sieber and selected him as one of his pupils. (Romanovich-Slavatinskij 1903)

Kiev had a specific position in the diffusion of political economy. The presence of Friedrich List in the curriculum reveals the concern for the incipient industrialization, but the dominant tendencies were the free-tradist "followers of Smith" (including its French representatives, such as Bastiat), and the German historical school.

Cekhanoveckij's lectures (1866) started with a very detailed exposition of the task of political economy, in a highly pedagogical style mixing utopian thinkers and science, and showing a taste for the history of economic doctrines. Cekhanoveckij understood the task of political economy as the resolution of the "probleme social" (quoted in French), namely to struck the right balance between the wealth of nations and the poverty of the mass of people. Cekhanoveckij referred to many different German, 
French and English authors, but three names appear most consistently in his lectures: Adam Smith, John Stuart Mill and Wilhelm Roscher. He rejected "the followers of Smith", who according to him confined themselves to abstraction, and believed, instead, that the German historical method was the only "positive" science that actually addressed the most urgent social questions (but he espoused Mill's teaching on cooperatives). In the lectures, Cekhanoveckij revealed his desire for social reforms and expressed his sympathy towards Proudhon against Bastiat. He also spoke of "antagonism of class", and claimed accusingly that: "the economists, representatives of the interests of the rich people, would like to limit the tasks of government to a very limited circle." (Cekhanoveckij 1866, 5, n³) He represented, in a nutshell, a kind of Kathedersozialist.

Bunge's lectures (Bunge 1869) combined English liberalism and protectionism. Ricardo, Storch and Say played a significant role in the text (taking the place of Smith and Mill in Cekhanoveckij's lectures), but for methodological issues Roscher remained the model to imitate for Bunge as well as for Cekhanoveckij. In the end, though, the structure of Bunge's lectures replicated that of Say's Traité: consumption, production (with productive services), exchange, distribution (wage, profit, rent, relation between the three types of income (see Bunge 1869). In his lectures, the chapter on exchange included a thorough theoretical discussion on value and prices. Bunge probably inspired Sieber's own approach to economic theory and his inclination toward abstract issues such as Ricardo's theory of value.

Sieber's own critical work developed from these sources and combined the theoretical approach of the Ricardians with the historical awareness of the Germans. Marx's Capital was not on the reading lists. According to Romanovich-Slavatinskij, it was Bunge, who supervised Sieber's master's examination in the early 1870 s, who 
"proposed that he explicate Marx's theory, which was then quite new." And Romanovich-Slavatinskij added: “I remember how Sieber's cheeks flushed when he began laying out the theory of which he became an avid proponent" (RomanovichSlavatinskij 1903).

The dissertation that Sieber defended in 1871 reflects this specific reading of Marx and established Sieber's reputation as a theoretical economist. He published it in journal and as a book in 1871 and continuously revised it during the 1870s until he published a new expanded edition in 1885. For Sieber, Marx showed the limits and contradictions of the two schools, the school of Smith and Ricardo, on the one hand, and the German school on the other, that competed for domination in the field of political economy.

Sieber began his book with a discussion of different theories of values brought forward by German, French and British political economists and he concluded that

Despite all of this variety, it is not difficult to notice that the English writers clearly differ from the Germans in their objective view of both utility and value. ${ }^{6}$ For the former, utility is simply the quality of objects that meets needs, and not of all objects, but only those objects that indeed fulfil their purpose. The latter, on the contrary, for the most part connect their concept of utility with a person's judgment of it. (Sieber 1871,10$)^{7}$

Sieber believed that the objectivist theory of value was significantly better than the subjectivist one. The Ricardian school, in particular, with the discovery of the labour theory of value had discovered its true foundation, by steering away from local, temporal and subjective elements. ${ }^{8}$ The Germans, instead, had developed an incoherent

\footnotetext{
${ }^{6}$ With Malthus and Senior being exceptions to a certain extent.

${ }^{7}$ Translation of Sieber's book by Jessica Mroz, page numbers refer to Russian.

8 "Sie setzt die Lokale, Temporelle, Subjektive immer soviel möglich in Entfernung, und steuert auf die allgemeinsten Grundsätze los," (Baumstarck quoted in Sieber 1871, 102)
} 
subjectivist theory that Sieber openly criticised in the first chapters of his book.

Subjectivist theories of values were not based on standard cases, but on exceptions, that German political economists had mistakenly taken for significant and normative (Sieber $1871,33)$

For Sieber, Marx "had brought to perfection" the British theory of value developed by Ricardo and his followers by developing the labour theory of value and discovering the implicit conflict that went with it. Far from being metaphysical, Marx's method, "as far as theory is concerned", was the "purely deductive method of all the English School” (Sieber 1871, 169). As a continuator of Ricardo, Marx had defined value in terms of the average human labour that entered in the production of a good. In developing his theory, he had relied on "normal" or "average" cases and discovered law-like regularities. By focusing on the general, average value of things, Marx was able to refuse the accusations moved by the like of Bastiat, MacLeod, and Walras against Ricardo's theory of value. While they speculated on ad-hoc imaginary examples, Marx investigated value as "determined in socially normal conditions of production and an average level of effectiveness and intensity of labour." (Sieber 1871, 170)

But Marx was not simply the continuator of Ricardo. Sieber remarked that the British school of political economy had made a fetish of the capitalist society and thought of categories such as capital, good, salary as eternal and universal. He lived in a society where capitalist relations of production were far from widespread. In the late 1860 s and early 1870 s, Kiev was not only an academic centre where professors were debating abstract and methodological ideas. It was precisely the "practical conclusions" that could be drawn from Marx's theory that made it so relevant for the intelligentsia of Kiev. The demand for credit was expanding, landowners had more capital available for 
productive investment, and new agricultural specializations emerged that depended on the expanding beetroot sugar and linen oil industries (Blackwell 1968, 53-55).

Moreover, the Black Sea ports of the Russian Empire were recovering their role as hubs of grain trade after the Crimean War.

Yet, the Southwestern provinces of the Empire seemed not to be industrializing at the same speed as Moscow and Saint-Petersburg and the whole of the Empire was lagging behind western European nations; emancipated serfs were struggling with the payment of their debt instalments and the workers attracted to the cities like Kiev were living in utter poverty. The dispute between protectionists and free-tradists, which was a common issue in late $19^{\text {th }}$ century Europe, combined with political discussion on the absolute monarchy, and issues of ethnicity (Blackwell 1968, 123-35).

Marx's critique of political economy, therefore, seemed so important to Sieber because he shared with many other Russians the perception that they were experiencing an epochal change. For Sieber, Marx possessed, instead, an acute "German" sense of history and steered away from naive "Robinsonade." He praised Marx for his understanding of capitalism as an historically and locally determined phenomenon. While the Russian populists who translated Marx's Capital finally concluded that the country was not following the same path of development of the Western European countries, and thus thought of Das Kapital as the description of evils to be avoided, Sieber's own empirical work and the work of his circles of friends in Kiev convinced him that the Russian Empire was not going to escape the laws of the global market.

\section{Between Lavrov and the Ukrainophiles}

Questions concerning political and economic development were acutely felt by students and professors who formed the core of the intellegentsia of Kiev. Sieber's membership of the Kiev's consumers' co-operative is the first evidence of his interest in 
the social question. In 1869, after writing an article on the co-operative movement for the Kievskij Telegraf newspaper, Sieber joined the founding members of the Kiev consumers' co-operative (Sieber 1869). ${ }^{9}$ The list of the co-operative founding member is revealing. Next to Sieber we find some of his colleagues at the University who were famous for their interest in Ukrainian culture and traditions and were to be accused later of being ukrainophiles, including historian Mikhail Petrovich Dragomanov, ethnographer Vladimir Bonifacevich Antonovich and his wife, jurist Aleksandr Fedorovich Kistjakovskij and his wife and archaeologist Viliam Ludvigovich Bernshtam. ${ }^{10}$

Sieber's political connections with the Ukrainian national and the socialist movement form are a controversial topic. This section documents Sieber's contacts with Petr Lavrov and the Russian socialists in exile and the extent of his participation in the activities of the Ukranian intellectual elite in Kiev between 1873 and 1875 .

This participation was glossed over by Sieber's biographers who wrote before 1917 (Chuprov 2009; Ja. 1890; Zuev 1898). After the Revolution and the consolidation of Bolshevik rule in the Ukraine, Mikhail Slabchenko (introduction to Sieber 1923) insisted on the consciously Ukrainian and revolutionary activity of Sieber, and the same did Mihailo Grushevs'kij (1922), who had been one of the leaders of the short-lived People's Republic of Ukraine. This position became increasingly untenable in the Soviet Union. Lev Klejnbort (1923), for instance, who relied heavily on the often

${ }^{9}$ CDIAK, 442, 47, 348, sheet 1-13, Delo ob otkritii v g. Kieve tovarishestva potrebitelej 19.8.1868-6.10.1868 prilagaetsja ustav tovarisshestva. On the government cautious support for co-operatives, see Figurovskaja and Institut èkonomiki (Rossijskaja akademija nauk) (1998, tom 1, kniga 3, chast' 1, p. 6).

${ }^{10}$ The full list of members appeared in "Otkrytie destvij kievskago tovarishchestva potrebitelej”, Kievkij Telegraf, N. 3, 6.1.1869. Antipenko (2012) considers Kistjakovskij a representative of the "liberal-democratic tendency" among "Ukrainian democrats" but also a supporters of social reforms in favour of "peasants and urban workers"; On Bernshtam, see Ivanic'ka (2012). 
superficial memorialist Ovsjaniko-Kulikovsij, ignored Sieber connections with the Ukrainophiles, but recognised him as a "true Marxist", while Naumov (1930) adopted a different strategy to salvage Sieber's legacy in the shrinking space left to political heterodoxy: he acknowledged his membership of the Ukrainian "Gromada" circle (see below) but denied any active content to this participation and turned Sieber into a purely "theoretical Marxist" engaged - but only in writing - in the fight against the "pseudoMarxism" of the likes of Lavrov. In the heydays of Stalinism, Abram Reuel carried this interpretation even further: he characterized the Ukrainian national movement as purely "liberal”, denied Sieber any political awareness and grotesquely decried as "Gestapo agents and counterrevolutionary trockists" all those who tried to "turn Sieber into a father of Marxism” (Reuel' 1937, xliv, 1956).

In this article, we underline instead that participation in the Ukrainian national movement was not incompatible with a commitment to revolutionary socialism. National movements were part of the broad socialist movement of the 1870 s and political federalism was a strategy of coping with the spread of capitalism and industrialisation. Sieber's statistical research carried out with the Ukrainophiles demonstrated precisely that capitalism - in accordance to Marx' prophecy - was expanding even into the rural Southwestern governorates of the Empire. While it is difficult to assess how active a member Sieber was of the revolutionary socialist movement and whether he felt part of the Ukrainian nation, he clearly participated in both movements.

In 1872, immediately after his book was out in print, Sieber left Kiev with a scholarship on a journey of instruction to Europe that was to be decisive for his life. Sieber visited Germany, Austria-Hungary, Switzerland and other European countries. The time he spent in Zurich was very productive. For a young economist educated on 
Ricardo and the German school, Switzerland presented a fascinating stratification of modern industry and rural commons whose dissolution was already under way due to the pressure from the community's demography and the market economy. Sieber paid attention to the forms of Swiss democracy (he attended, for instance, the Landsgemeinde in Glarus that rejected a proposal of constitutional amendment in May 1873 ) and to the Swiss consumers' and producers' co-operatives (Sieber 1873; Masoero 1995). In Switzerland the old forms of the pre-capitalist society merged with the new forms of the capitalist society and with new social phenomena - such as the cooperatives and the unions - that were only imitative in Kiev but had a real life in Zurich.

During this period outside the Russian Empire, Sieber probably also established relationships with Russian political activists abroad. Both Leipzig - where Sieber attended the university classes - and Zurich were important centres of Russian student emigration. "In Zurich - Kropotkin wrote in his memoirs - a great number of Russian students lived at that time, and also Peter Lavrovich Lavrov.” (Kropotkin 2011; Eaton 1980; McClellan 2005)

In Zurich, the Russian community gravitated around the Russian Library, a collection of books shared by the Russian émigrés, whose librarian was Rozalija Idel'son, a student of medicine from Kiev. ${ }^{11}$ The life of the Russian Library and surrounding community of students was complicated by the struggle between supporters of Bakunin and of Lavrov. ${ }^{12}$ It is probably through Idel'son's husband, the physician Valerian Smirnov, that Sieber and his friend Sergej Podolinskij became acquainted with

\footnotetext{
${ }^{11}$ For an interesting portrait of the Russian community in Zurich during the 1870 s, see Kuljabko-Koreckij (1931, 42-48).

${ }^{12}$ On the Russian Library, see Kankowski-Züllig (1991); Kropotkin recalls the conflict culminating with the beating of Valerian Smirnov, and mentions the presence of a typography belonging to the Chajkovskij group (Kropotkin 2011).
} 
such a charismatic figure of the Russian revolutionary movement as Lavrov. ${ }^{13}$ When their correspondence began, Lavrov had recently escaped from Russia. He was convinced that politics in Russia had to change radically, but he was also persuaded that before starting a revolution, the young educated Russians had to study and educate the people around them. He introduced a specifically intellectual element in the Russian revolutionary movement. For this reason, he was trying to open a journal, Vpered (Itenberg and Tvardovskaja 1988; Pomper 1972).

Lavrov tried to involve Podolinskij and Sieber in the making of his journal. Podolinskij eventually volunteered to smuggle copies of Vpered and other books into the Southwestern governorships of Russia. Sieber's role is less clear, but he might have actually been crucial for the success of the project. In February 1873, Valerian Smirnov obtained from the government in Zurich the authorization to print the journal there. The state-councillor of Canton Zurich who actually reassured Smirnov that the authorities would not interfere was Johann Caspar Sieber, a relative of Nikolaj Sieber if we are to believe the far from infallible memory of Kuljabko-Korecki. ${ }^{14}$

Sieber's return to Kiev to occupy a position of "docent by the chair of political economy" at the St. Vladimir University, in autumn 1873, marked the beginning of a new phase also in the political activity of his circle. ${ }^{15}$ Sieber's Kiev period coincided with the brief flourishing of the Ukrainophiles in the late 1860 s and early 1870 s and reflected this political climate. In the Southwestern governorates, in particular, in the wake of the Polish revolt of 1863 , the Imperial power and the Ukrainian elites tried a

\footnotetext{
${ }^{13}$ The correspondence between Podolinskij Smirnov and Lavrov has been published to a great extent in Sapir (1970, vols. 2, appendices); Danila Raskov found two letters exchanged by Sieber and Lavrov at the MGA.

${ }^{14}$ V. N. Smirnov to V. M. Aleksandrovich, Zurich, 6.02 .1873 (in Sapir 1970, 61; Sapir incorrectly identified Jo. Ka. Sieber with N. I. Sieber). See Kuljabko-Koreckij $(1931,57)$.

${ }^{15}$ DAK, fond 16 opys 314 dela 163 , sheet 25 .
} 
relaxation of the norms against the Ukrainian national movement, hoping to limit the influence of Polish nationalists (Hillis 2012).

In July 1874, the Kievskij Telegraf, one of the two main newspapers in Kiev, changed hand. The new owner, Avdotija Gogockaja, managed to gather around the newspaper a group of academics - largely overlapping with membership of the abovementioned consumers' co-operative - that comprised the literary scholar Mikhaj1 Dragomanov, Romanovich-Slavjatinskij, the natural scientist Sergej Podolinskij, the historian Ivan Vasilevich Luchickij, Antonovich, and Sieber among others. They turned a sleepy provincial newspaper into a very dynamic outlet for economic and political discussions that originated in their academic and political interests, in competition with the conservative newspaper Kievljanin. ${ }^{16}$ Podolinskij, who also contributed to the newspaper, claimed the publication was only allowed because the group bribed the Censor in Kiev, but, to underline the politically marked character of the newspaper, he added that the police still considered writing for the Kievskij Telegraf almost as criminal as smuggling Vpered into Ukraine. Publishing on the newspaper characterized the authors as belonging to or sympathizing with the so-called Kiev "Gromada."17

An exact characterization of this group is difficult. The "Gromada" was dedicated to raising national awareness in Ukraine, and many in the group were "Ukrainophiles," interested in promoting Ukrainian language and culture, documenting the folklore, the history and the archaeology of the "Little-Russians."18 But Podolinskij described the Ukrainophiles as the "Ukrainian Social-Democratic Party" and stated that

\footnotetext{
${ }^{16}$ The Kievljanin was published by Mikhail Aleksandrovich Juzefovich who was the director of Kiev archaeological committee and the curator of cultural activities in Kiev for the central government.

${ }^{17}$ CDIA, 1865-1875, Delo o cenzurnom prosmotre statej, pomeshenniykh v otdel'nykh nomerakh izdavaemoj v g. Kieve gazety "Kievskij Telegraf". Imeetsja programa gazety ukazan god osnovanija. Redaktor Snezhko Blockij, 294, 1, 4, sheets 1-64.

${ }^{18}$ When writing in Russian, the authors discussed in this article used the word malo-russkie or "Little-Russians" to define Ukrainians.
} 
their program was "similar to the anarchists of western Europe, not to the extremists, such as the Spaniards, but to those of Jura and the anarchic group of Belgium." ${ }^{19} \mathrm{He}$ had attended the International Working Men's Association (IWA) Congress in The Hague in 1872, and he was clearly struggling to reconcile Lavrov's cautious revolutionary ambitions with a more active, Bakuninist action. ${ }^{20}$ His reference to the Belgian socialist Caesar de Paepe probably reveals the meaning of the group's Ukrainophilia. ${ }^{21}$ De Paepe was one of the main supporters of a socialist federalism inside the International. But federalism was an essential part of the socialist movement in this period. Even Marx, in the Civil war in France, "went a long way towards accommodating the federalist ideals espoused by the leaders of the Commune" (Stedman Jones 2017, 507). Struggles of national and class liberation intertwined in the "Gromada" 's opposition to the Russian autocracy.

Sieber's contributions to the Kievskij Telegraf and the census plan he prepared for the Southwestern branch of the Imperial Geographical Society show an equal interest for social and ethnic questions. The Southwestern branch of the Imperial Geographical Society was established in 1872 by some of Sieber's colleagues at the university. ${ }^{22}$ On 2 March 1874, its members - including Antonovich, Chubinskij, Bernshtam - carried out a one-day census of the population of Kiev. ${ }^{23}$ Sieber prepared the census questionnaire for the society to provide "a factual balance sheet of this or that group of the population, rather than mere examples." A balance sheet (also called a

\footnotetext{
${ }^{19}$ Letter from S.A. Podolinskij to Smirnov, 17.05.1875 (in Sapir 1970, vols. 2, 439 and 445).

${ }^{20}$ See Podolinskij (1880a), originally published in Vienna in 1875, which witnesses his involvement with the radicals.

${ }^{21}$ Sapir (1970, vols. 2, 444f) assumes that Podolinskij referred to De Paepe (1874), which was published in Russian in Vpered! in 1875. On de Paepe and the federalist and collectivist stream of socialism he represented, see the rare biographical essay contained in Dandois (1974).

${ }^{22}$ CDIAK Fond 442 Opis 51 Delo 106 list 1-89.

23 "Izvlechenie iz Otcheta o dejatelnosti Jugo-Zapdnago Otdela Imper. Russk. Geograficheskago Obschestva za 1875 g.", Kievsij Telegraf, 1875, N. 48, p. 2.
} 
budget) - a typical format for social reformism in the second half of the 19th century ${ }^{24}-$ surveyed the community's production and consumption. This, in turn, meant analysing the "forms" and the "size" of production, transport and consumption. But questions about production and consumption presupposed questions about the social, demographic and ethnic structure of the population. Patterns of production and consumption determined social, demographic and ethnic issues and were determined by them. Sieber, therefore, expected questions contained in the first part (concerning gender, age, ethnicity) and in the second part of the questionnaire (concerning the economy) to be cross-checked. In this way, the researcher - in a manner characteristic of 19th century nationalistic theorising - could make apparent how each ethnic group (the Jews, the Poles, the Little and Great Russians, etc.) contributed to the economy and what their standard of living was in terms of wealth, education and morals (Sieber 1875, $3-4)$.

Sieber's statistical plan was applied in Kiev, as witnessed by an anonymous article in the Kievskij Telegraf and in the national journal Znanie in 1876 signed by Sieber. ${ }^{25}$ The author of the article on housing in Kievskij Telegraf deplored the conditions of workers and the poor state of housing and bravely stressed the government's inability to improve the life of the poor. Sieber's article on Znanie, instead, was more academic and neutral, but the census of ethnic identities of great-, little-, and white-Russians remained a deeply controversial topic, even when presented as a division of a unique Russian people:

\footnotetext{
${ }^{24}$ The method of budgets was developed in particular by Frédéric Le Play and his followers (see Kalaora and Savoye 1989).

${ }^{25}$ The article "O zhilishhakh bednago naselenija Kieva" (On Housing of the Poor Population in Kiev) appeared in the Kievskij Telegraf in January 1875, N. 6, signed N. It could have been authored by Sieber or by S. V. Zavojko, but Sieber's authorship is more likely. The results of the census were published in 1875 by the society (Southwestern Branch of the Imperial Russian Geographical Society 1875); see also Sieber's publication in Znanie (Sieber 1876b, III, 31).
} 
"the indignant cry of the local sophisto-patriots contributed no little to make the question of people's mother-tongue murkier and raised endless misunderstandings about the determination of the different sorts of Russian."

The "sophistopatriots," namely Russian nationalists, did not refrain - Sieber complained - from publicly reprimanding the census organisers for daring to count white-, little- and great-Russians separately (Sieber 1876b, III, 54). ${ }^{26}$

The comparison between Saint-Petersburg and Kiev that Sieber carried out in Znanie is interesting for understanding the development of Sieber's Marxism. The article showed that, while both Kiev and the capital were essentially administrative and military centres (in both cities, the most numerous group of "productive workers" were the domestic servants), Saint Petersburg was far more advanced than the Ukrainian city "in the path towards the development of capitalist production instead of the old handicraft production.” (Sieber 1876b, IV, 2) The comparison stressed how Kiev was lagging behind Petersburg in terms of the spread of the factory system, by showing how the category of owner-entrepreneur and specialized workers still dominated in most sectors of production. Nevertheless, the data also revealed the emergence of some kind of factory system in the tobacco, distilling and sugar industry. The clearest sign of the impending development of capitalism, though, was the appearance, in both cities, of a significant group of "day labourer” (podenschiki) living of occasional jobs. Sieber interpreted these as the free-hands of industrial take-off: "This is usually the state of things in those places where ... the handicraft forms did not begin to die, but the factory forms are not yet fully alive" (Sieber $1876 \mathrm{~b}, \mathrm{IV}, 42$ ). But the number of such free hands would soon grow as the factory system developed. Meanwhile, the census data depicted

\footnotetext{
${ }^{26}$ The Ministry of public education also claimed that that census had been the work of Ukrainophiles, even trying to increase the number of little-Russians with respect to other ethnic groups, CDIAK Fond 707 opys 261 delo 17.
} 
instead the utter destitution of handicrafts and their falling living standards even in comparison to peasants.

Sieber never imagined a different form of development, casting a pessimist shadow on the populist dream of a non-capitalist path for the future of Russia. In this period, he was intensely working on the economic and social theory of capitalism and writing on Marx, probably encouraged by Marx's own praise of Sieber's first book that appeared in the second German edition of Das Kapital. Sieber is said to have been "lecturing" on Marx at the private gatherings of Kiev Gromada, according to Naumov (1930). In January 1874, Znanie published the first instalment of Sieber's “The economic theory of Karl Marx" (Sieber 1874) ${ }^{27}$. Sieber's article seem to share the same interest in a physiological definition of human labour as the source of value, based on physical dispersion of heath and metabolic process, that was characteristic of his friend Podolinskij (1880b; see Burkett and Bellamy Foster 2008). Eventually, Sieber seems to have concentrated his interest on the historical development of societies, as we will see.

Meanwhile, the activity of these circles had attracted the attention of the authorities. The Ministry of Public Education, in January 1875 was already discussing the Kievskij Telegraf and the Imperial Geographical Society as instruments of a "Party of Ukrainophiles", headed by Chubinskij, hiding behind the prestige of Antonovich. ${ }^{28}$ The repression was swift. Mikhail Dragomanov, one of the leaders of the Gromada group was forced to resign from his position at the University in 1875. The Kievskij Telegraf was shut down by order of the Imperial Government in $1876 .{ }^{29}$ The

\footnotetext{
${ }^{27}$ It has been translated into English (Sieber 2011; see the translator's introduction: White 2011).

${ }^{28}$ CDIAK, fond 707 opys 261 delo 17.

${ }^{29}$ According to Podolinskij, letter to Lavrov, Vienna 15.08.1875, the USDP group had actually left the redaction of the Kievskij Telegraf on 1st August 1875, because of disagreements with Gogockaja (Sapir 1970, vols. 2, 450).
} 
Southwestern branch of the Imperial Geographical Society was closed and its endowments transferred to Juzefovich' Archeological Committee. ${ }^{30}$ The same order of the Central Administration for the Affairs of the Press that put an end to the Kievskij Telegraf contained an overall ban on all publications in the Ukrainian language. ${ }^{31}$ But by the time the Kievskij Telegraf ceased its publications, Sieber was not in Kiev anymore: in May 1875 he and his wife Nadezhda Olimpievna Schumova-Sieber had left the Russian Empire for the Swiss Confederation and on 15 May 1875, the Siebers reached Bern. ${ }^{32}$

The Third Section (the formidable Russian political police) believed that Sieber had "fled to Switzerland with Dragomanov" and it is possible that he emigrated to Switzerland because of the new political climate at the University in Kiev. ${ }^{33}$ After the civil war of 1847 , democratic and socially progressive Switzerland became a real safeharbour for victims of political persecution from all over Europe. ${ }^{34}$ But Bern had

${ }^{30}$ Juzefovich had been denouncing the "ukrainofilia" of the Society since he resigned from membership in April 1875, CDIAK, fond 442, opis 825, delo 41, list 1-04.

${ }^{31}$ CDIAK, O prekrashenii izdanija gazety Kievskij Telegraf. Iz predpisanija Glavnogo upravlenija po delam pechati ot 4 Junija $1876 \mathrm{~g}$., Fond 442, Opis 388, delo 73 is interesting essentially for two reasons: it contains an order from the Third section (the political policy) dated 28.8.1875 to the governor of Kiev to create a committee that should include Juzefovich "due to the appearance of ukrainophile activities and particularly of translations and printing of handbooks and prayerbooks in the little-Russian language." This order is followed on 10.6.1876 by a decision of the Central administration for the affairs of the press, N. 3148, ordering not to allow documents printed in Ukrainian to enter the borders of the Empire or to be published inside the Empire and ordering to "cease any further publications of the newspaper Kievskij Telegraf'. Up to point 4, this order was included in the circular letter N 3570 sent on 23.6.1876 that repeats the N. 3148 literally except that it does not include mention of the Kievskij Telegraf. It must have been a very important case, though, decided at the highest level of the Russian state. See also CDIAK, O zakritii gazety Kievskij Telegraf. Iz soobsshenija nachal'nika kievskogo okhrannogo otdelenia ot 8 Maja 1876 g., Fond 274, opis 1, delo 3226, 193f. On the genesis of the Ems decree, see Remy (2007).

${ }^{32}$ SAB 12781 4, Fremdenregister Niedergelassene IV $(1872$ - 1884).

${ }^{33}$ GARF f. 109, op. 230, d. 1741, 1. 1-3.

${ }^{34}$ In any case, Sieber left Kiev without waiting for the necessary documents. The SaintVladimir University of Kiev officially accepted Sieber's resignation from the post of professor only in December 1875, when Sieber was already in Bern, DAK, fond 16, opys 314 delo 163, sheets 16-20. The documents were sent to Sieber's mother in Jalta. 
another reason of appeal for the Siebers. Sieber's wife was very determined to achieve a higher education, and Bern was a natural (almost, the only) choice for Russian women who wanted to graduate in medicine. ${ }^{35}$ Studying abroad could have been part of the plans of the couple since they met and got married. ${ }^{36}$

\section{Studying social change}

Despite his departure for Switzerland, Sieber continued visiting the Russian Empire (and this shows that the police was not particularly interested in his whereabouts) and remained in contact with Russian academic circles. Alongside old Ukrainian connections (Dragomanov, Kostomarov), Sieber could count on academic friends interested in Marxism. The latter were the editors of important journals and contributed to permeate Russian academic culture with Marxism. In this section, we show how Sieber, despite censorship, managed to leave a significant imprint on Russian Marxism, publishing, as Klejnbort $(1923,16)$ stated "in almost all the progressive journals." His “most important articles" posthumously listed in Brockhaus and Efron's Conversation Dictionary (Ja. 1890), which means that they were legally acceptable, include his writings openly dedicated to Marx and his surveys of the empirical literature on the effects of capitalism on traditional societies. The list stressed his significance essentially as a scientist of societal change. His critique of populism and the insistence on the decadence of communal forms of properties in Russia and elsewhere influenced both the emergence of the so-called "legal Marxism" - which stressed the positivity of

${ }^{35}$ All of the 27 female students at the University of Bern in the Winter semester 1875-76 came from the Russian Empire. Of them, 25 studied at the Medical School, one at the Law School, and one at the Faculty of Philosophy. Ekaterina Shumova, Nadezhda's sister, enrolled one semester before the Siebers arrived (Universität Bern 1875). On the experience of Russian female students in Bern, see Rogger (1999); Rogger and Bankowski (2010).

${ }^{36}$ Getting married was a characteristic way to emigrate and study abroad for young Russian women. This had been for instance the case of Idel'son, who is said to have entered in a sham-marriage in order to go to Switzerland (Kuljabko-Koreckij 1931, 15-16). 
the capitalist phase of development - and the ideas of the revolutionaries who were to found the Russian social-democracy.

Sieber developed an important activity as a contributor to the Russian "thick journals" of this time. ${ }^{37}$ The so-called "thick journals" of the $19^{\text {th }}$ century contained articles on different topics interesting for a cultivated public: politics, economics, literature, ethnography, etc. Such journals offered the main legal forum for debating public issues, within the narrow limits allowed by the censors. Besides the already mentioned Znanie-Slovo, Sieber published in the Otechestvennie Zapiski, in Kriticheskoe Obozrenie, in Juridicheskij Vestnik, in the Vestnik Evropy and in Russkaja Mysl'. These were some of the main journals of this period and big names such as Dostoevskij and Tolstoj published on their pages. ${ }^{38}$

Some characters neatly emerge among Sieber's connection in the world of Russian legal journals. A group of scholars of law and of economics at the Faculty of Law of the University of Moscow was closely connected with the journals to which Sieber contributed. Law professor Maksim M. Kovalevskij, economists Ivan I. Janzhul and Aleksandr I. Chuprov and statistician Nikolaj A. Kablukov were all connected with Juridicheskij Vestnik. Kovalevskij, Kablukov and Janzhul also wrote for Kriticheskoe Obozrenie and the newspaper Russkie Vedomosti. Kablukov published in Russkaja Mysl', while Kovalevskij and Janzhul were active in Otechestvennie Zapiski. The editor of Zapiski, Nikolaj K. Mikhajlovskij, an intellectual close to the first Narodnaja Volija, also collaborated with Russkie Vedomosti and Russkaj Mysl' (Dement'ev, Zapadov, and Cherepakhov 1959). This was probably one of the first groups of Russian scholars

\footnotetext{
${ }^{37}$ Rezul' (1931) counts a total of 46 articles between 1876 and 1888, excluding those of his works "published in Kriticheskoe Obozrenie, Vol'noe Slovo, Kievskij Telegraf and Russkie Vedomosti." Incredibly, he claims that "Sieber's collaboration to these journals is already more or less well documented" (143).

${ }^{38}$ The cathegory of "thick journals" with reference to Russia is discussed in Maguire (1997). See also Belknap (1997).
} 
interested in Marx, even if they remained for most of their life part of the legal intellectual establishment of the Empire.

But Sieber's Ukrainian connections were probably extremely important in granting him access to these journals. For instance, in 1868, Antonovich became one of the editors of Otechestvennie Zapiski (Antonovich and Zhukovskij 1869). The case of Vestnik Evropy has been studied by Pogorelskin and reveals a significant presence of Ukrainophiles in the life of the journal. Pogorelskin stressed the link between one of the main contributors to the journal, Aleksandr N. Pypin, and the historians and ethnographers Kostomarov and Dragomanov. Pypin was Chernyshevkij’s cousin and struggled to keep memory of his proscribed cousin alive during the years of Chernyshevskij's exile (Pogorelskin 1978, 1987, 1993). ${ }^{39}$ It was probably through this channel that Sieber could publish in this journal.

What we know of Sieber's network in the world of periodicals is enough to show his connections with the major intellectuals of the Russian "progressives." This term is used here in a very loose way to cover different streams of thought and different degrees of radicalism. What most intellectuals of this period shared was a conception of political activity that combined with the study of society, which broadly included ethnography and economics. Sieber was clearly considered an expert on economic issues and published a number of commentaries on major economic trends, stock exchange crashes, and new labour laws. As soon as he settled down in Switzerland he resumed publishing "The economic theory of Karl Marx" on Znanie and then on Slovo when the former journal was shut down by the Main administration for the affairs of the press. Sieber discussed topics that could endangered the survival of journals. In 1875,

\footnotetext{
${ }^{39}$ Interestingly - but it could be a mere coincidence - B. I. Utin, another key contributor and among the founders of the journal, was the brother of N. I. Utin - the founder of the first Russian section of the IWA in Geneva.
} 
for instance, the Main administration for the affairs of the press issued a warning to Znanie concerning the diffusion of "materialism." Marxism and in 1879 published a series of extracts from Engel's Anti-Dühring under Sieber's name (Sieber 1879a).

Actually, Sieber's articles were often presented as reviews of published foreign books and contained long translated excerpts of the work discussed. In one case, extensively commented below, it was not possible to identify the author of a sharp criticism against John Stuart Mill that Sieber declares to have translated and excerpted. Omitting the name of controversial authors could have been a strategy adopted to lower the risk of censorship: Sieber for instance never mentioned the name of Friederich Engels in his summary of the Anti-Dühring. His selection of books to review highlighted the most perverse effects of ruthless capitalism, but also how capitalism and the factory system were spreading world-wide. For the readers of Znanie, Sieber selected Otto Glogau's (notoriously anti-semitic) works on the stock-exchange crash of Vienna and Berlin of 1873 which insisted on the catastrophic results of reckless financial speculation, but Sieber was keen to distinguish mere "corruption," which could occasionally occur, and the inevitable development of financial capitalism and systematic economic crises. ${ }^{41}$ In 1882 on the pages of Russkaja Mysl', Sieber commented in "Trend of the world economy in the past decade" by reviewing the Übersichten der Weltwirthschaft by Franz Xaver von Neumann-Spallart and underlined that

\footnotetext{
${ }^{40}$ RGIA, F. 776, op. 6, delo 245, list 75, 11 December 1875; Salz-Jacobson explained the transition from the preventive to the reactive system of censorship in Nikitenko and Jacobson (1975, xvi).

${ }^{41}$ Sieber (1876a); Glogau's anti-semitism is discussed in Raphael $(1995,109)$.
} 
Since the second half of the current century, the functions of that complicated whole that we name "world economy", in opposition to the individual national economies, have emerged with increasing strength. (Sieber 1882b)

And he then explained how European states abolished market restrictions between provinces and during the 1860s custom duties went down at least until 187778. Even if a period of protectionist policies followed,

The force of facts demands unhindered reciprocal trade relationships to continue without restraint. (Sieber 1882b)

The "force of facts" led to the creation of large trade blocs among state, of the postal and telegraphic union, etc. toward a sort of "cosmopolitical union" of the World (Sieber 1882b).

Sieber also commented on land-ownership patterns and their evolution, especially the demise of communal properties. This stream of literature evolved into a consistent interest for ethnographical and historical writing (Sieber 1878, 1879b, 1880, 1881a, 1881c, 1881b, 1882d, 1882c). While the world market extended, it dragged more and more regions of the world into the capitalist economy, but non-capitalist forms of production remained important. From a theoretical point of view, Sieber believed that it was important to show the historically-determined nature of capitalism, but he also wanted to show that non-capitalist societies were dissolving. His articles/reviews on the evolution of rural commons in Switzerland, Germany and India were addressing the well-known Russian debate on the viability of the rural commune, the obshchina, and the future of Russia. Sieber's intervention on Otechestvennie Zapiski in November 1877, in response to Julij Galaktionovich Zhukovskij's criticism of Marx, insisted on capitalism as a world-wide phenomenon which would by necessity lead to the 
dissolution of non-capitalist forms of production (J. G. Zhukovskij 1877; Mikhailovskij 1877; Sieber 1877).

This polemic consecrated Sieber's credibility as an interpreter of Marx. In fact, as White $(1996,240 \mathrm{ff}$.$) stressed, Marx was also tempted to intervene in the debate and$ wrote a letter to the editors of journal to the express his more nuanced view on the inevitability of capitalism, but refrained from doing so, maybe for fear of undermining Sieber. In February 1881, Vera Zasulich referred probably to this exchange, that included other participants beside Sieber and Zhukovskij, in her famous letter to Marx on the future of the Russian rural community. Sieber's article must have left a profound impression on the Russian revolutionaries, as Aksel'rod wrote:

The fact is that around the time I was in Saint-Petersburg, the question of the future of the obschina was upsetting the populist youth. I don't remember now whether it was only under the influence of the articles by Sieber - the first Russian Marxist but only in a strictly economic sense - or also under the impression of some literary sketches of country life - some representatives of this youth developed anxious doubts regarding the possibility of saving the obschina from dissolution. (Aksel'rod 1923, 351-52)

And the Imperial Gendarmes in May 1884 found Sieber's and Mikhailovkij's popular articles in response to Zhukovskij together with a six-shot revolver while searching the house of some students suspected of revolutionary tendencies. ${ }^{42}$

\section{The emergence of the Russian social-democrats and the first Marxist}

\section{Orthodoxy}

As we said, the Soviet debate since the 1930s concentrated on the issue: was Sieber a real Marxist? Naumov stressed the purely theoretical character of Sieber's Marxism and defined him a "precursor of the legal Marxists of the 1890s" (Naumov

${ }^{42}$ CDIAK, f. 442 o. 834 d. 60 , sheet 64. 
1930, 92-93). Soviet historians Abram Reuel and Nikolaj Tsagolov denied that he understood the revolutionary meaning of Marx (Reuel' 1937; Cagolov 1953), while others called him a precursor of legal Marxism. In fact, their historiographical categories are probably not very useful to understand the debate of the $1870 \mathrm{~s}$. It is difficult to reconstruct the exact evolution of his position, between the followers of Lavrov, the Bakuninists, the populists of Zemlja $i$ Volija and Dragomanov, who continued occupying a central position in the community of exiles (Zasulich 1913; Dragomanov 1880). Here we underline that his insistence on capitalism as a historical but world-wide phenomenon, as well as on the necessity of a gradual approach to the revolution, marked an increasing distance from the populists. Yet, we document that the revolution - however the term is to be understood - and the end of capitalism remained a crucial element of his world-view. He proved a decisive influence on a group of breakaways from Zemlija i Volija who, eventually became the Emancipation of Labour group and the first nucleus of the Revolutionary Social-Democratic Party of Russia.

In a letter dated from Paris on 12 March 1878, Lavrov mentioned an article promised by Sieber for publication in Obshchina, a periodical based in Geneva and edited by a diverse group of social-revolutionaries, including Nikolaj I. Zhukovskij, Sergej M. Kravchinskij, Arbore Ralli and Aksel'rod (Sapir 1974, 513). It remains unclear what Sieber had in common with the initially anarchist Aksel'rod and with the adventurous Kravchinskij or the populist Nikolaj Zhukovskij, who believed that postrevolutionary Russia would be in the hands of rural communes. ${ }^{43}$ It seems that this journal, close to the populist Zemlija $i$ Volija, was putting in practice Lavrov's repeated appeals for unity of action of all revolutionary forces.

43 "Both Aksel'rod and Kravchinskij were orthodox followers of Bakunin at that time." (R.S.F.S.R 1924): Zhukovskij claimed that the objective of the organisation of which Obshchina was an organ (the Social-revolutionary party?) was "the federal, provincial and communal autonomy” (N. Zhukovskij 1878, 4; our emphasis). 
For one thing, Obshchina was very attentive to the national liberation and federalist movements of Poles and Little-Russians and frequently hosted articles by Dragomanov, Kravchinskij regularly contributed with observations on Ukraine. Another characteristic of the journal was the interest in Marx's political position and the IWA. If Sieber really intended to publish in this journal, this would prove a significant level of engagement in the socialist and anti-centralist movement of the Russian exiles.

Many years afterwards, Aksel'rod recalled that it was Sieber, during a conversation they had in Bern in 1878 , who persuaded him that anarchy could not be achieved immediately, but required instead a radical transformation of society, including "as a necessary objective pre-requisite":

the ability of members of society and the real possibility for all of them to fulfil in turn all the different functions of social production and the administration of the country, and to participate directly to the control of this administration. And this, in turn, requires, as an objective necessary pre-condition, such a high development of machine-production and economic technique more in general, and such a high level of cultural and intellectual development of the masses as can only be achieved in a socialist society, namely only after a victorious revolution (Aksel'rod 1923).

For this gradualist approach, which he traces back to the influence of Sieber, Aksel'rod was immediately accused of being a "social-democrat" by his fellow comrades in Zemlja $i$ Volja. And indeed, Sieber's belief in the gradually transforming forces of the market clashed with the populists' convictions but was not equivalent to a renouncement of revolutionary ideals. It showed, instead, the germs of Menshevism.

In 1879 , Sieber translated for the Russian journal Slovo a pamphlet that reveals at the same time the sincerity of his revolutionary sentiments, the extent of his proximity to Marx' politics and his distance from the Narodniki. This pamphlet, "Objections to the economic doctrines of John Stuart Mill," presented a surprisingly 
concise illustration of Marxist doctrines on class struggle and capitalist development. For the author of the pamphlet, as for Sieber, the law of competition necessarily involved the destruction of small scale agriculture and industry. Indeed, any attempt by traditional societies to defend the old way of life was misguided and lead to more and more human suffering (Sieber 1879c). Implicitly, a similar faith would await Russia if it persisted in the attempt to preserve the remnants of the old institutions, the autocracy and the rural commune. Resistance was futile. Sieber approvingly translated the passage of "Objections to the economic doctrines of John Stuart Mill” where the unknown author of this booklet criticised Mill's lack of consequence, arguing that real changes in society would not be possible until the government was in the hand of the capitalists,

until the members of the government are nominated by one class only, they will have to serve the interests of such a class and protect it with all the force of the law ... no individual charitable feeling (blagonamerennost') will allow the government to redirect production toward the satisfaction of the necessities of society rather than toward the creation of profit for a few owners of capital. (Sieber 1879c)

In 1879, as it is well known, Zemlija i Volija split into Narodnaja Vol'ja and Chernyj Peredel. ${ }^{44}$ Through Aksel'rod, Sieber exerted a significant influence on the chernoperedel'tsy (Zasulich, Deich, Plekhanov, Aksel'rod, Ignatov) and was key in converting them to Marxism. ${ }^{45}$ Exchanges extended over the years at least until 1882: in a rare surviving letter, Sieber asked whether it was Aksel'rod who had got his copy of

\footnotetext{
${ }^{44}$ Lavrov basically accepted that the primacy of the terrorist Narodnaja Vol'ja, at the beginning of the 1880s, and, in contrast with the pedagogical approach he had defended until then against the anarchists, came to see the revolution as an imminent possibility (Pomper 1972, 204ff).

${ }^{45}$ Rjazanov acknowledged Sieber's influence on Plekhanov while at the same time diminishing the former's role: "incomparably more influence on Plekhanov was exerted by the early Russian Marxist, N. Sieber, whom Plekhanov, in his first programmatic article, called 'one of the most talented students and vulgarisators of Marx"” (in Plekhanov 1923).
} 
Zur Kritik, ${ }^{46}$ and in June 1882, Evgenij (Dejch) invited Aksel'rod to ask Sieber for an issue of Slovo (Plekhanov, Zasulich, and Dejch 1923, 165 n.1).

Sieber's own relationship with the populists seems to have worsened at this point. While Ovsjanko-Kulikovsij claimed that Sieber never engaged in direct polemics with the populists, in 1882, Sieber did not refrain from frontally attacking the populist V. P. Voroncov, who believed that Russia's future rested in the obshchina. In his review of Voroncov's Capitalism in Russia, Sieber insisted on the relative progress of Russian capitalism, criticising Voroncov's use of data. As anticipated by the censuses of 1876, Russia was following the path of all other countries in the West: industry was growing and employment in production for the market was replacing production for autoconsumption. ${ }^{47}$ Sieber's review culminated with a statement against moderate top-down reforms: "The time has passed, when such changes could be considered a graceful present that can be taken back any minute." ${ }^{48}$

According to Janzhul, in January 1881, a month before Zasulich sent her famous letter to Marx, Sieber was in London, spending his days at the Library of the British Museum together with Kablukov, Janzhul and others (Janzhul 2005, 182-86). Sieber went to London and subsequently Paris because he needed English books and reports for the book he was writing, Ocherki pervobytnoj ekonomicheskoj kultury (Essays on

${ }^{46}$ Ziber to Aksel'rod, 5.8.1881, Archives of the IISH, 139.45a.

${ }^{47}$ Sieber (1882a), extensively discussed in Dubjanskij (2016).

${ }^{48}$ Sieber's article was published in Geneva on the columns of the newspaper Vol'noe Slovo. Apparently, Vol'noe Slovo, which was edited by Mikhail Dragomanov and A. P. Malshinskij was a project of a secret organisation, the Svjataja Druzhina, established by some Russian conservative aristocrats and functionaries in order to fight the revolutionary movement. Malshinskij was actually a spy in the service of the Third Section (Russia's secret police) and his intent in founding the newspaper was to split the exiles community in Geneva, by voicing a moderate liberal-constitutional position. The controversies around this newspaper continued until the 1960s. Then B. V. Anan'ich and R. Sh. Ganeli even tried to demonstrate that Dragomanov had been an accomplice of the Svjataja Druzhina under the orders of Sergej Ju. Vitte, future Finance minister of the Empire, (Anan'ich and Ganeli 1964). 
primitive economic culture) which was published in 1883 in Moscow with the practical help of Chuprov. ${ }^{49}$ According to Lawrence Krader $(1976,25)$, in this period, Marx was also intensively working at the Library and compiling the bulk of his ethnographical notebooks. Sieber and his Russian friends met Marx in this occasion, and it is very unlikely that they did not discuss what was for all of them a burning topic, namely the fate of non-capitalist societies, including the rural parts of the Russian Empire.

The book of 1883 culminated the long series of articles on this topic that put Sieber in obvious contrast with the narodniki. The book concentrated on the question of communal property and set up to investigate whether it really was a universal institution among the so-called "primitive" peoples. By exploiting reports from countless travellers to extra-European regions, Sieber traced the origin of communal ownership, not in agricultural societies, but in hunters' and herders' societies, the first example being not land but tools and weapons. He insisted on the historical, and therefore transient, nature of communal ownership. Maksim Kovalevskij, in his book on common property, which Sieber had reviewed in 1880, had insisted on the violent destruction of the commune in India brought about by the British neglect for the canalization works that underpinned it (Sieber 1880). Sieber mentioned a similar example of violent death of communal institution when describing the Spanish expansion in Moorish and American land. ${ }^{50}$ But the main driver of the dissolution of the commons appeared to him to be the division of labour that transformed the original indistinct communities of blood (rody). The death of rural commons was caused by impersonal and irresistible forces.

\footnotetext{
${ }^{49}$ In Paris he met Ovsjanko Kulikovskij who recalls the meeting in his memoirs. "In 1881 and 1882 we saw each other often in Paris, where Sieber had come to study in the National Library. He was at that point studying literature on savages, having set for himself the goal of tracing the process of how legal and ethical norms arose based on the economic conditions of so-called 'primitive cultures'. Again I listened to a number of his improvised lectures, which were of enormous interest to me" (quoted in Raskov 2018).

${ }^{50}$ Sieber $(1883$, 44-45; quoted in Raskov 2018, see also 2016).
} 
To Sieber, actually, Marx and historical materialism seemed to offer the appropriate global theoretical framework to address the historical transformation of society. Marx, therefore, was not a simple continuator of Ricardo's political economy, but, despite his debt toward the British economist, a real critic of political economy. Zur Kritik and Das Kapital provided the Russian researcher with a consistent theory of how economic realities drove historical change towards a fully capitalist society and beyond through different stages of disaggregation of the original natural community. For this reason, it would be unfair to say that he did not understand the revolutionary potential of Marx's theory. ${ }^{51}$ Historical awareness also shaped Sieber's understanding of the revolutionary dialectic aspect of Marx's thought. This appeared in all evidence only a few years later, in 1885, when a second - enlarged - edition of his 1871 dissertation, newly entitled David Rikardo i Karl Marks, saw the light in Moscow (again thanks to Chuprov). Chapter IV of the new edition had more than doubled in size but, in reality, the bulk of the chapter was now formed by an almost verbatim translation of the first chapter Marx's Capital. Sieber also included long passages from the Afterword to the second German edition of 1873, especially those famous passages were Marx defended himself from the accusation of being "metaphysical." Dialectics

regards every historically developed social form as in fluid movement, and therefore takes into account its transient nature not less than its momentary existence; because it lets nothing impose upon it, and is in its essence critical and revolutionary. (Marx 1873)

${ }^{51}$ Shtejn (1948, 194; on which, see Shirokorad 2012, 75; and Krandievskij 1966) grouped Sieber with the "legal Marxists", while Poljanskij (1965) - and maybe not without good reasons - insisted on his failure to understand the revolutionary role of proletariat; on the latter authors, see also Guelfat (1970). 


\section{Epilogue: back to case one}

In 1884, Sieber and his sister travelled back to Crimea despite the fact that he had been wanted by the imperial police since 1881 . Sieber was gravely ill and retired to Jalta with his mother and sister where he led a quiet life until his death in 1888. In his obituary, Chuprov remembered his friend as a pure theoretician: "Within political economy, Nikolaj Ivanovich dedicated himself not so much to practical questions, which occupy the majority of specialists nowadays, as, instead, to the theoretical, philosophical side of the issue" (Chuprov 2009, 323). Chuprov's judgement is somewhat misleading. As we saw, practical, applied questions occupied Sieber as much as his friend. His early activity as statisticians, the attention he dedicated to the business cycle and land distribution betray Sieber's interest in economic and social realities. Yet, Chuprov is accurate in so far Sieber subordinated the study of concrete problems to the general outline of historical, or dialectical, development. His research on the rural commons, on primitive societies, on factory workers, on housing in big cities, etc. were intended to show how capitalism contrasted with and came to supplant other modes of production, following the expansion of the world market.

Because of the theoretical framework he provided, Sieber exerted a long-lasting influence on Russian social-democrats, including Lenin. His reading of Marx established among the Russians - until the revolution of 1917 - the idea that a capitalist phase, dominated by private property of the means of production and by a trend towards the concentration of capital, was a historical necessity. If Sieber influenced the socialdemocrats, especially the future Mensheviks, a study of his intellectual biography reveals the persistence of many elements that were typical of the socialist movement in the 1860 s and 1870 s. In his circle of friends, if not in his own writings, the national question was central. Struggles for national liberation appeared as necessary 
complements of the socialist revolutionary struggle, especially within the Russian and Austro-Hungarian Empires.

Even the forms of Sieber's political engagement bear the mark of the 1870s. Soviet historians often denied his active participation to the socialist struggle. Nevertheless, his writings are sometimes explicit about revolutionary change. Most likely, what pushed later interpreters and younger friends to dismiss Sieber's activism was the fact that he did not took part in the efforts of organising a party and his activity preserved the moderate character typical of the early followers of Lavrov in the $1860 \mathrm{~s}$ and 1870s. It privileged education and research - however controversial - over political agitation and revolt organising. Moreover, to many Soviet scholars, his attitude towards capitalism must have seemed tainted with the same flaws as the Menshvik program of Plekhanov and Aksel'rod. ${ }^{52}$ This does not make Sieber a socialist of the chair - a mild advocate of social reform who expected the government to intervene in favour of the workers - nor a kind of legal Marxist who denied the necessity of a socialist revolution. Sieber lived among revolutionaries. He believed in the inner contradictions of capitalism as of any previous mode of production and did expect the collapse of Russian autocracy and Western bourgeoisie, but he remained - in many ways - a Marxist before Marxism.

\section{List of Archives:}

CDIAK: Central Historical State Archive of Ukraine in Kyiv, Central'nij Derzhavnij Istorichnij Arkhiv Ukraini, Kyiv.

DAK: State Archives in the City of Kyiv, Derzhavnij arkhiv mista Kieva, Kyiv.

GARF: Gosudarstvennyj Arkhiv Rossiskoj Federacii, State Archive of the Russian Federation, Moscow.

IISH: International Institute for Social History, Amsterdam.

\footnotetext{
${ }^{52}$ On Soviet historiography on Plekhanov, see Pokidchenko (2017).
} 
MGA: Moskovskij Gorodskoj Arkhiv, Moscow State Archive, Moscow

SZH: Stadtsarchiv Zuerich, City Archive, Zurich

SAB: Stadtsarchiv Bern, City Archive, Bern

\section{References}

Aksel'rod, Pavel B. 1923. Perezhitoe i Peredumannoe. Berlin: Izd. Z. I. Grzhebina.

Allisson, François. 2015. Value and Prices in Russian Economic Thought: A Journey inside the Russian Synthesis, 1890-1920. London ; New York: Routledge, Taylor \& Francis Group.

Anan'ich, and R. Sh. Ganeli. 1964. “S. YU. Vitte, M. P. Dragomanov, i «Vol'noe Slovo». (Po Povodu Odnogo Dokumenta Iz Arkhiva M. K. Lemke).” In Sbornik Statej, Posvyashchennyj 75-Letiyu Prof. S.N. Valka., edited by AN SSSR. Institut istorii. Leningradskoe otdelenie., 163-78. Trudy. Vyp. 7. Issledovaniya Po Otechestvennomu Istochnikovedeniyu. Moskva-Leningrad.

Antipenko, A. S. 2012. "Lichnost' A. F. Kistyakovskogo v Svete Istochnikov." Intelligencija $i$ Vlast' 26: 186-94.

Antonovich, M. A., and Ju. G. Zhukovskij. 1869. Materialy Dlja Kharakteristiki Sovremennoj Russkoj Literatury Postscriptum. Soderzhanie i Programma «Otech. Zapisok» Za Proshlyj God. Sankt Petersburg: Tip M. A. Katomina.

Bankowski-Züllig, Monika. 1991. "Die Erste 'Russische Bibliothek in Zürich' (18701873).” In “Der Parnass Liegt Nicht in Den Schweizer Alpen.” Aspekte Der Zürcher Universitätsgeschichte, edited by Verena Stadler-Lahart, 229-59. Zürich: Rohr.

Belknap, Robert L. 1997. "Survey of Russian Journals, 1840-1880.” In Literary Journals in Imperial Russia, edited by Deborah A Martinsen, 91-116.

Blackwell, William L. 1968. Beginnings of Russian Industrialization, 1800-1860. Princeton, N.J: Princeton University Press.

Bühler, Roman, Heidi Gander-Wolf, Carsten Goehrke, Urs Rauber, Gisela Tschudin, and Josef Voegeli. 1985. Schweizer in Zarenreich. Zur Geschichte Der Auswanderung Nach Russland. Zürich: Verlag Hans Rohr.

Bunge, Nikolay Khristianovich. 1869. “Osnovanija Politicheskoj Èkonomii: Potrebnosti, Proizvodstvo, Razdelenie Truda, Obmen, Dokhody i Ikh Naznachenie." Universitetskie Izvestie (Kieva) 12-1-2-3-4: 1-35, 1-34, 1-19, 1$39,1-12$.

Burkett, Paul, and John Bellamy Foster. 2008. "The Podolinsky Myth: An Obituary. Introduction to 'Human Labour and Unity of Force', by Sergei Podolinsky." Historical Materialism 16: 115-161.

Cagolov, N. A. 1953. "K Kharakteristike Èkonomicheskikh Vzgljadov N. I. Zibera." Voprosy Èkonomiki 9.

Cekhanoveckij, Grigorij Matveevich. 1866. "Kratkij Obzor Politicheskoj Èkonomii (A Short Outline of Political Economy)." Universitetskie Izvestie (Kieva) 3 and 4: $1-44$ and $1-33$.

Chuprov, Aleksandr Ivanovich. 2009. Rossiya Vchera i Segodnja. Moskva: Russkij Mir.

Dandois, Bertrand. 1974. Entre Marx et Bakounine: César De Paepe. Correspondance. Montepellier et Paris: Maspero.

De Paepe, César. 1874. De l'organisation Des Services Publics Dans La Société Future - Mémoire Présenté Du Congrès de Bruxelles Au Nom de La Section Bruxelloise En 1874. Bruxelles: D. Brismée. 
Dement'ev, A. G., A. V. Zapadov, and M. S. Cherepakhov, eds. 1959. Russkaja Periodicheskaja Pechat' (1702-1893). Eni "Periodika," Electronic version. Moskva: Gosudarstvennoe izdatel'stvo politicheskoj literatury. http://febweb.ru/feb/periodic/default.asp?/feb/periodic/pp1/pp1.html.

Dragomanov, Mikhail Petrovich. 1880. Zhenevskoe Obshchestvo Posobija Politicheskim Izgnannikam Iz Rossii: Ustav. Geneva: Hromada. http://data.rero.ch/01-R007587990/html?view=GE_V1.

Dubjanskij, Aleksandr Nikolaevich. 2016. "Ziber i Voroncov o Kapitalisticheskom Puti i Razvitija Rossii." Terra Economicus 14 (4): 107-18.

Eaton, Henry. 1980. "Marx and the Russians." Journal of the History of Ideas 41 (1): 89-112.

Figurovskaja, N. K., and Institut èkonomiki (Rossijskaja akademija nauk), eds. 1998. Kooperacija - Stranicy Istorii. Pamjatniki Ėkonomicheskoj Mysli. Moskva: Nauka.

Grushevs'kij, Mihajlo. 1922. Z Pochiniv Ukrains'kovo Socijalistichnogo Rukhu. Vena. Guelfat, Isaac. 1970. "Aux Sources de La Marxologie Authentique: N. I. Ziber." L'Homme et La Société 17 (3): 141-48.

Hillis, Faith. 2012. "Ukrainophile Activism and Imperial Governance in Russia's Southwestern Borderlands." Kritika: Explorations in Russian and Eurasian History 13 (2): 301-26. https://doi.org/10.1353/kri.2012.0019.

Itenberg, Boris Samuilovich, and V. A. Tvardovskaja. 1988. P.L. Lavrov v Russkom Revoljucionnom Dvizhenii. Moskva: Nauka.

Ivanic'ka, Svitlana. 2012. “Ukraïns'kij Shistdesyatnik» Vil'yam Berenshtam Doslidnik Miscevih Starozhitnostej." Kraeznastvo 1: 57-66.

Ja., V. 1890. “Ziber, Nikolaj Ivanovich.” In Encikolpedicheskij Slovar' Brokgauza i Efrona. St. Petersburg: Brockhaus and Efron.

Janzhul, Ivan Ivanovich. 2005. "Vospominanija I. I. Janzhula o Perezhitom i Vidennom v 1864-1909 Gg." In Izbrannye Trudy, edited by M. G. Pokidchenko and E. N. Kalmychkova, 29-356. Rossijskaja Ėkonomicheskaja Mysl'. Moscow: Nauka.

Kalaora, Bernard, and Antoine Savoye. 1989. Les Inventeurs Oubliés: Le Play et Ses Continuateurs Aux Origines Des Sciences Sociales. Collection Milieux. Seyssel [France]: Champ Vallon.

Klejnbort, L. N. 1923. Nikolaj Ivanovich Ziber. Petrograd: Kolos.

Krader, Lawrence. 1976. "Einleitung." In Die ethnologischen Exzerpthefte, by Karl Marx, edited by Lawrence Krader, translated by Angelika Schweikhart, 1. Aufl. Edition Suhrkamp 800. Frankfurt am Main: Suhrkamp.

Krandievskij, Semen Ivanovich. 1966. "Ocherki Po Istoriografii Èkonomicheskoj Istorii (XVII-XIX).” Kiev: AN USSR. Otd-nie ehkonomiki, istorii, filosofii i prava.

Kropotkin, Petr Alekseevich. 2011. Zapiski revoljucionera. St. Petersburg: Azbuka.

Kuljabko-Koreckij, Nikolaj Grigor'evich. 1931. Iz Davnikh Let : Vospominanija Lavrista. Moskva: izd. Polit-katorzhan. http://elib.shpl.ru/ru/nodes/21982kulyabko-koretskiy-n-g-iz-davnih-let-vospominaniya-lavrista-m1931\#page/11/mode/inspect/zoom/4.

Maguire, Robert A. 1997. "Introduction.” In Literary Journals in Imperial Russia, edited by Deborah A Martinsen, 1-10. Cambridge: Cambridge University Press.

Marx, Karl. 1873. "Afterword to the Second German Edition." In Capital: A Critique of Political Economy. Volume I: The Process of Capitalist Production, 16-26. New York: The Modern Library.

Marx, Karl, and Friedrich Engels. 1999. Die Bibliotheken von Karl Marx Und Friedrich Engels. Annotiertes Verzeichnis Des Ermittelten Bestandes. Edited by Hans- 
Peter Harstick, Richard Sperl, and Hanno Strauss. Marx Engels Gesamtausgabe (MEGA), IV/32. Berlin: Akademie Verlag.

Masoero, Alberto. 1995. "Paysages sociaux et itinéraires de formation: Les voyages d'études des économistes russes à l'étranger, années 1860 et 1870." Cahiers $d u$ monde russe : Russie, Empire russe, Union soviétique, États indépendants 36 (1): 7-35. https://doi.org/10.3406/cmr.1995.2419.

McClellan, Woodford. 2005. Revolutionary Exiles. The Russians in the First International and the Paris Commune. London: Routledge.

Mikhailovskij, N. K. 1877. "Karl Marks Pered Sudom g. Ku Zhukovskogo." Otechestvennye Zapiski 10.

Mullin, Richard. 2015. The Russian Social-Democratic Labour Party, 1899-1904: Documents of the "Economist" Opposition to Iskra and Early Menshevism. Historical Materialism Book Series, volume 84. Leiden; Boston: Brill.

Naumov, D. B. 1930. Nikolaj Ivanovich Ziber Iz Istorii Ėkonomicheskoj Mysli Na Ukraine i v Rossii. Kiev: izd. "Proletarii."

Nikitenko, A., and Helen Saltz Jacobson. 1975. The Diary of a Russian Censor. Amherst: University of Massachusetts Press.

Pavlenko, Ju. V. 2012. Narody, Civilizacii, Chelovechestvo: Problema Identichnosti. Kiev: Feniks.

Plekhanov, Georgij Valentinovich. 1923. Sochinenija. Edited by D. Rjazanov. Vol. 1. Moskva: Gosudarstvennoe izdatel'stvo.

Plekhanov, Georgij Valentinovich, Vera Zasulich, and L. G. Dejch. 1923. Gruppa "Osvobozhdenie truda": sbornik. Moskva: Gosudarstvennoe izdatel'stvo.

Podolinskij, Sergej A. 1880a. Socialisty Ukraincy v Avstrii. Geneva: Red. de la "Hromada." . 1880b. "Trud Cheloveka i Ego Otnoshenie k Raspredeleniju Energii." Slovo 45: 135-211.

Pogorelskin, Alexis E. 1978. "N. I. Kostomarov and the Origins of the Vestnik Evropy Circle." Oxford Slavonic Papers 11: 84-100. - 1987. "Vestnik Evropy and the Polish Question in the Reign of Alexander II." Slavic Review 46 (01): 87-105. https://doi.org/10.2307/2498622.

—. 1993. “A. N. Pypin's Defence of Ukraine: Sources and Motivation.” In Ukrainian Past, Ukrainian Present: Selected Papers from the Fourth World Congress for Soviet and East European Studies, Harrogate, 1990, edited by Bohdan Krawchenko, 35-54. London: Palgrave Macmillan UK.

Pokidchenko, M. G. 2017. "Plekhanov Kak Istorik Obshhestvenno-Èkonomicheskoj Mysli.” Istoriko-Èkonomicheskie Issledovanija 18 (4): 599-612.

Poljanskij, F. Ja. 1965. Plekhanov i Russkaja Èkonomicheskaja Mysl'. Moskva: Izd-vo Mosk. un-ta.

Polyanskij, Fedor Yakovlevich. 1965. Plekhanov i Russkaya Èkonomicheskaya Mysl'. Moskva: Izdatel'stvo Moskovskogo universiteta.

Pomper, Philip. 1972. Peter Lavrov and the Russian Revolutionary Movement. Chicago: University of Chicago Press.

Raphael, Freddy. 1995. "Der Wucherer.” In Antisemitismus: Vorurteile Und Mythen, edited by Julius H. Schoeps and Joachim Schlör, 103-18. München: Piper.

Raskov, Danila. 2016. "N.I.Ziber Kak Kabinetnyj Èkonomist-Antropolog.” Terra Economicus 14 (4): 92-106.

2018. "Networks, Fields, and Political Economy in Fin-De-Siècle Russia: The Life and Work of Nikolai Sieber." In Re-Examining the History of the Russian Economy. A New Analytic Tool from Field Theory, edited by Jeffrey K. Hass, 
97-125. Basingstoke: Palgrave Macmillan UK.

Remy, Johannes. 2007. "The Valuev Circular and Censorship of Ukrainian Publications in the Russian Empire (1863-1876): Intention and Practice." Canadian Slavonic Papers 49 (1-2): 87-110. https://doi.org/10.1080/00085006.2007.11092432.

Reuel', Abram L. 1937. "Predislovie." In David Rikardo i Karl Marks v Ih Obshhestvenno-Èkonomicheskikh Issledovanijakh (David Ricardo and Karl Marx in Their Social-Economical Researches), by Nikolaj Ivanovich Sieber, Gos. soc.-èkon. izd. Moscow.

. 1956. "N.I. Ziber Kak Nauchnyj i Obshchestvennyj Dejatel' v Rossii 70-Ikh i Nachala 80-Kh Godov XIX Veka." In Russkaja Ekonomicheskaja Mysl' 60-70Kh Godov XIX Veka i Marksizm. Moskva: Gospolitizdat.

Rezul', Ja. G. 1931. 'N. I. Ziber (Bibliografija).” Katorga i Ssylka 7: 142-74.

Rogger, Franziska. 1999. Der Doktorhut Im Besenschrank: Das Abenteuerliche Leben Der Ersten Studentinnen, Am Beispiel Der Universität Bern. 1. Auflage. Bern: Ef-Ef-Verlag.

Rogger, Franziska, and Monika Bankowski. 2010. Ganz Europa Blickt Auf Uns! Das Schweizerische Frauenstudium Und Seine Russischen Pionierinnen. Baden: Hier + Jetzt.

Romanovich-Slavatinskij, A. B. 1903. Golos Starogo Professora Po Povodu Universitetskikh Voprosov. 2nd ed. Kiev.

R.S.F.S.R. 1924. Materialy Po Istorii Russkogo Revolyucionnogo Dvizheniya T. p. Russkij Revolyucionnyj Arkhiv v g. Berlin. Berlin: Tipografija "Vorwärts."

Sapir, Boris. 1970. Vpered! 1873-1877: From the Archives of Valerian Nikolaevich Smirnov. Dordrecht: Reidel Publishing Company. . 1974. Lavrov-Gody Emigracii: Arkhivnye Materialy v Dvukh Tomakh. Russian Series on Social History 2. Dordrecht ; Boston: Reidel.

Shirokorad, Leonid D. 2012. “V. M. Shtejn i Kampanija Bor'by s Kozmopolitizmom: Dramaticheskaja Sud'ba Odnoj Knigi.” Vestnik Sankt-Peterburgskogo Universiteta, 5, 1: 60-71.

Shtejn, Viktor Moricovich. 1948. Ocherki Razvitija Russkoj ObshhestvennoÈkonomicheskoj Mysli XIX-XX Vekov. Leningrad: Izd-vo i tip. Leningr. gos. ordena Lenina un-ta.

Sieber, Nikolaj Ivanovich. 1869. “O Potrebitel'skikh Tovarischestvakh.” Kievskij Telegraf, February 19, 1869. . 1871. Teorija Cennosti i Kapitala Rikardo s Nekotorymi Iz Pozdnejshikh Dopolnenij i Raz"jasnenij (David Ricardo's Theory of Value and Capital in Relation to the Latest Contributions and Interpretations). First edition. Kiev: Univ. Izd. 1873. "Otchet Magistra Politicheskoj Èkonomii Nikolaja Zibera o Prebyvanii Za Graniceju s" Janvarja Po Oktjabr' 1872 Goda.” Universitetskija Izvestija (Kieva) 1: 55. 1874. "Ekonomicheskaja Teorija Marksa." Znanie I: 43-90. 1875. Opyt Programmy Dlja Sobiranija Statistiko-Ekkonomicheskikh Svedenij : Sost. d. Chl. Otd. N.I. Ziber Dlja Yugo-Zap. Otd. Imp. Rus. Geogr. o-Va. Kiev: tip. M.P. Frica. . 1876a. "“Berlinskie Grjunderi i Ikh Moshennichestvo - Otto Glogau. Der Börsen- Und Gründungsschwindel in Berlin- Leipzig 1876." Znanie IX: 33-89. 1876b. "Materialy Dlja Nabljudenija Nad Obshhestvenno-Èkonomicheskuju Zhizn'ju Russkogo Goroda (Materials for the Observation of the Social and Economic Life of a Russian City)." Znanie III-IV: 30-81, 1-77. 
1877. "Neskol'ko Zamechanij Po Povodu Stat'i G. Ju. Zhukovskogo 'Karl Marx i Ego Kniga o Kapitale.”' Otechestvennye Zapiski XI: 1-32.

. 1878. 'Obschino-Pozemel'nie Otnoshenija Vladel'cheskikh Krest'jan El'zasa v Srednie Veka." Otechestvennye Zapiski, no. 9 and 12: 129-56 and 319-67. . 1879a. "Dialektika v Ee Primenenii k Nauke." Slovo XI: 117-69.

. 1879b. "K Istorii Russkoj Osbschiny: N. A. Sokolovskij 'Ekonomicheskij Byt Zemledel'cheskogo Naselenija Rossii i Kolonizacii Jugo Vostochnykh Stepej Pered Krepostnym Pravom."' Slovo, no. VIII: 196-209. . 1879c. "Vozrazhenija Na Ekonomicheskoe Uchenie Millja." Slovo VII and IX: $139-78$ and $75-120$.

. 1880. "K Istorii Obschinnogo Zemlevladenija. M. Kovalevskij, 'Obschinnoe Zemlevladenie, Prichiny, Khod i Posledstvija Ego Razlozhenija. Ch. I.

Obschinnoe Zemlevladenie v Kolonijakh." Juridecheskij Vestnik, no. VIII: 673-92.

. 1881a. "Eshche o Bratstvakh (Po Povodu Stat'i A. Efimenko “juzhno-Russkie Bratstva)." Slovo, no. I: 177-260.

—. 1881b. “Istorija Shvejzarskoj Al'mendy." Vestnik Evropy, no. X: 601-32.

1881c. "Obshchina i Gosudarstvo v Niderlandskoj Indii." Otechestvennye Zapiski, no. III: 79-128.

_. 1882a. "Kapitalizm v Rossii." Vol'noe Slovo, no. 41: 1. . 1882b. “"Khod Vsemirnogo Khozjajstva v Poslednee Desjatiletie."” Russkaja Mysl' VII: 65-98.

—. 1882c. "Novyj Trud o Pervobytniykh Uchrezhdenijakh." Otechestvennye Zapiski, no. VII: 151-202.

. 1882d. "Sud'ba Obschinnogo Vladenja v Shvejcarii." Vestnik Evropy, no. VII: $41-73$.

1883. Ocherki Pervobytnoj Ekonomicheskoj Kultury. Moskva: Tip. Rikhter V. F.

1885. David Rikardo i Karl Marks v Ikh Obshhestvenno-Ėkonomicheskikh Issledovanijakh (David Ricardo and Karl Marx in Their Social-Economical Researches). St. Petersburg: Tip. M. N. Stasjulevich.

. 1923. Ocherki pervobytnoj èkonomicheskoj kul'tury so vstup. statej M. E. Slabchenko. Edited by Mikhail E. Slabchenko. Odessa: Gos. izdatel'stvo Ukrainy.

. 2011. "Marx’s Economic Theory." Research in Political Economy 27: 155190.

Southwestern Branch of the Imperial Russian Geographical Society. 1875. Kiev i Ego

Predmestiya Po Perepisi 2 Marta 1874 G. Kiev: tip. Un-ta sv. Vladimira.

Stedman Jones, Gareth. 2017. Karl Marx: Greatness and Illusion. London: Allen Lane.

Universität Bern. 1875. Behoerden, Lehrer Und Studirende Im Winter Semester 1875-

76. Bern: Buchdruckerei Jent und Reinert.

Vol'kov, Feliks, and Aleksandr Rusov. 1907. "Premechenija." Byloe 2 (6): 153-60.

Walicki, Andrzej. 1969. The Controversy over Capitalism. Studies in the Social Philosophy of the Russian Populists. Oxford: Clarendon Press.

White, James D. 1996. Karl Marx and the Intellectual Origins of Dialectical Materialism. Houndmills, Basingstoke, Hampshire; New York: Macmillan Press ; St. Martin's Press.

White, James D. 2011. "Nikolai Sieber: An Introduction to a Political Economist Approved by Marx." Research in Political Economy 27: 151-154.

White, James D. 2019. Marx and Russia. The Fate of a Doctrine. The Bloomsbury 
History of Modern Russia Series. London: Bloomsbury.

Zasulich, Vera. 1913. “'Vol'noe Slovo' i Ėmigracija.” Sovremennik, no. 6.

Zhukovskij, Ju. G. 1877. "Karl Marks i Ego Kniga o Kapital." Vestnik Evropy 9.

Zhukovskij, Nikolaj. 1878. "Reformy i Revolucija." Obshchina, no. 5.

Zuev, G. 1898. "Pamjati N. I. Zibera." Odesskie Novosti, April 29, 1898. 